Article

\title{
Greenhouse Gas Implications of Peri-Urban Land Use Change in a Developed City under Four Future Climate Scenarios
}

\author{
Alison Rothwell ${ }^{1, *}$, Brad Ridoutt ${ }^{2,3}$ and William Bellotti ${ }^{4}$ \\ 1 School of Science and Health, Western Sydney University, Locked Bag 1797, Penrith, NSW 2751, Australia \\ 2 Commonwealth Scientific and Industrial Research Organisation (CSIRO), Private Bag 10, Clayton South, \\ VIC 3169, Australia; brad.ridoutt@csiro.au \\ 3 Department of Agricultural Economics, University of the Free State, Bloemfontein 9300, South Africa \\ 4 Global Change Institute, The University of Queensland, Global Change Institute Building (20), Level 3, \\ Staff House Rd, St Lucia, QLD 4072, Australia; w.bellotti@uq.edu.au \\ * Correspondence: a.rothwell@westernsydney.edu.au; Tel.: +61-408-222-246
}

Academic Editor: Andrew Millington

Received: 8 June 2016; Accepted: 9 December 2016; Published: 16 December 2016

\begin{abstract}
Present decisions about urbanization of peri-urban (PU) areas may contribute to the capacity of cities to mitigate future climate change. Comprehensive mitigative responses to PU development should require integration of urban form and food production to realise potential trade-offs. Despite this, few studies examine greenhouse gas (GHG) implications of future urban development combined with impacts on PU food production. In this paper, four future scenarios, at 2050 and 2100 time horizons, were developed to evaluate the potential GHG emissions implications of feeding and housing a growing urban population in Sydney, Australia. The scenarios were thematically downscaled from the four relative concentration pathways. Central to the scenarios were differences in population, technology, energy, housing form, transportation, temperature, food production and land use change (LUC). A life cycle assessment approach was used within the scenarios to evaluate differences in GHG impacts. Differences in GHG emissions between scenarios at the 2100 time horizon, per area of PU land transformed, approximated $0.7 \mathrm{Mt} \mathrm{CO}_{2}$-e per year. Per additional resident this equated to 0.7 to $6.1 \mathrm{t} \mathrm{CO}_{2}$-e per year. Indirect $\mathrm{LUC}$ has the potential to be significant. Interventions such as carbon capture and storage technology, renewables and urban form markedly reduced emissions. However, incorporating cross-sectoral energy saving measures within urban planning at the regional scale requires a paradigmatic shift.
\end{abstract}

Keywords: climate change mitigation; peri-urban development; urban development scenarios; greenhouse gas emissions; life cycle assessment

\section{Introduction}

Recognition is growing of the contribution urban areas make to greenhouse gas (GHG) emissions and their potential role in mitigative efforts [1]. Existing urban areas have been estimated to contribute approximately 40 percent of global anthropogenic GHG emissions on a production basis, and in excess of 70 percent on a consumptive basis [2]. The capacity of cities to participate in strategies to minimise emissions is therefore large. Present day understanding of how different development pathways may impact future land availability and emissions generation should be improved. However, limited scientific understanding exists of the reductions in emissions magnitude that may be obtained through altering urban form [1]. Scenarios of future urban development, illustrative of alternative GHG concentration trajectories, have a vital role to inform policy. The four scenarios presented herein 
provide insight into how differences in housing and feeding growing urban populations may affect GHG emissions generation relating to area of peri-urban (PU) land use change (LUC).

Particular to mature, developed cities, mitigation options include urban regeneration strategies that encourage compact form, mixed land use, reductions in travel and rehabilitation of older buildings [1]. Mixed land use may include, for example, PU agricultural support. However, growing cities typically consume PU agricultural land for monofunctional housing use, causing displacement of commercial food production to more remote locations. Present decisions about urban development in PU areas have the potential to make an important difference to the vulnerability of large cities to future climate change. Comprehensive mitigative responses to future urban development should require integration of urban form and food production to realise potential trade-offs. Despite this, few studies examine the GHG implications of future urban development combined with the impact on PU food production displacement.

Missing from future PU development scenarios has been consideration of the land-use activities displaced by urban expansion. For example, displacement of commercial PU fresh food production and how this displacement affects overall GHG impact in addition to that of the installed urban form. Applications of climate scenarios at city and continental scale have occurred, such as those to ascertain future urban demand for land [3-8]. Long-term in temporal scope, these scenarios differed from most urban planning strategies that are not typically linked to global environmental change [7]. However, compounding environmental effects due to the activities displaced by urban demand for land were not assessed. A second gap in application of climate scenarios to PU development includes the lack of exploration into the magnitude of differences in GHG emissions trends between scenarios at future time points. Transport and household energy use have been used to contrast the magnitude of emissions between alternate urbanisation approaches for an agricultural county in the USA [8], however a general scarcity of such information exists.

PU LUC was selected as the lens through which GHG emissions were viewed for three principal reasons: competition for land use; current volume of PU horticultural production in the study area; and relative emissions of land currently used for horticulture versus urban use. PU areas are highly contested transitional zones between existing urban districts and rural areas. Decisions on LUC are fraught with opposition. Regarding the second reason, commercial PU agriculture, specifically horticulture, has importance in its large contribution to local and regional markets combined with significantly higher output than other forms of urban agriculture. For example, farms located near New York, USA, produced over 80 percent of the fruits, vegetables and milk produced in New York state in 2012 [9]. In Sydney, by dollar value, 53 percent of lettuce and 27 percent of the horticultural produce of New South Wales originate from PU production [10]. Compare this to recent estimates of intra-urban vegetable production, which contributes less than one percent by production value $[10,11]$. Thirdly, recent research indicates that GHG emissions from urban land use are 58 times greater on average than emissions from crop production [12]. Decisions that potentially increase the GHG emissions burden of cities, due to LUC in PU areas, need to be evidence-based.

In this paper, four future scenarios were developed to evaluate the potential GHG emissions implications of feeding and housing a growing urban population. The scenarios were based on the GHG concentration trajectories of the four relative concentration pathways (RCPs) [13]. The RCPs were adopted by the Intergovernmental Panel on Climate Change (IPCC) and define four potential climate futures [14]. The context for the scenarios was for a developed and growing city such as Sydney, Australia. A life cycle assessment (LCA) approach was used within the scenarios to evaluate differences in GHG impacts. The application of LCA within an exploratory scenario approach builds on prior work integrating both housing and food production changes in the current day [15].

The scenarios are considered exploratory as an infinite number of possible futures exist that may describe emissions and their driving forces [16]. Exploratory scenarios assist understanding of future uncertainty by describing and analysing possible (as opposed to probable) alternative futures given a set of climate, socio-economic and technology assumptions. Scenario thinking is one of a suite of 
pluralistic strategic responses used in public policy to construct solutions to uncertain climate change issues. Effective management of future uncertainty, in order to inform good policy, requires multilevel evaluation of alternative strategies and scenarios supported across institutional boundaries and at local and regional scales [17]. Scenario thinking is not intended to provide "the answer" to a problem [18]. Rather, exploration assists society and policy makers to choose a preferred course of action. Exploring the potential GHG emissions incurred through the necessity to both feed and house a growing urban population, under different future climate scenarios may provide momentum for more detailed and comprehensive strategic planning studies.

Prior work has established that displacing commercial PU fresh vegetable production (in this example, lettuce) with housing in greenfield areas typically generates a poorer environmental outcome compared to retention of PU food production through use of infill housing $[15,19]$. Building climate resilient pathways would therefore imply developing local PU fresh food producing capacity, but such investment would not reflect the development norm in a city such as Sydney. With urban population increasing, planning for future housing and fresh food production at lower relative emissions is vital to avoid infrastructure lock-in risks (such as housing form) that may compromise future efforts at mitigation. However, future GHG ramifications, and other environmental trade-offs, due to displacing commercial PU fresh food production in favour of more remote production to feed a local city market remain underexplored. This study builds on the novel approach used in [15], expanding examination to future GHG impacts resulting from different urban growth scenarios.

To examine the potential GHG emissions relating to the four urban development scenarios, specific objectives within this study included, firstly, interpreting the main characteristics of the four Relative Concentration Pathways, RCPs 2.6, 4.5, 6 and 8.5 [20-23]. Secondly, generating qualitative narratives representative of how housing and agricultural development may occur in a developed city. Thirdly, explanatory variables representing key differences between scenarios were identified and quantified. Finally, changes in explanatory variables were applied to life cycle inventory (LCI) for each of the four scenarios at time horizons 2050 and 2100 in order that GHG impact could be compared. Each scenario was required to house the respective future population with consequent determination of area of PU horticultural land displaced by housing. Food production from more remote locations was required to supply the city market at equivalent quantities to that displaced.

\section{Materials and Methods}

The aim of this study was to investigate the trends in GHG emissions between four future urban development scenarios. In all scenarios, the growth in urban population at the relevant time horizon required housing and the quantity of fresh food displaced, due to absorption of PU food producing land by housing, required replacement. Hence each scenario has differing amounts of new housing stock in two disparate locations, on either existing urban or existing horticultural land, to accommodate a growing population. Therefore differing degrees of PU horticultural LUC to housing occurs between scenarios. GHG emissions results for each scenario were reported by area of PU land consumed to house the change in population.

Each scenario included both a housing and a fresh food production system. For the housing system, the ratio of two disparate housing types was adjusted in each scenario: new houses in PU, greenfield locations where horticulture is the current land use; and infill apartments in existing suburban centres. Existing PU land use was regarded as horticultural, with consumption by greenfield housing at an amount particular to each scenario and time horizon. Horticultural production displaced by housing was required to be replaced from more remote production locations. The horticultural system was modelled as field grown lettuce. Reasons for choice of lettuce included: lettuce is the dominant vegetable produced in the Sydney region; is dominantly field grown; is produced year-round; approximately 88 percent of the quantity consumed in Sydney is produced in the region [10,24]; and regionally specific data was available from both the Sydney PU and interstate regions. Lettuce was assumed to be delivered to the Sydney central fruit and vegetable market in Homebush, NSW. Upstream LUC 
impacts occurring due to further potential upstream crop displacements was considered. The housing and food systems have been described in detail in [15].

\subsection{Scope}

The method uses Sydney, Australia, to illustrate the principle of accounting for both horticultural change and housing development to obtain comprehensive mitigation strategies for urban growth. Sydney is a large city representative of how a developed city may grow. However with consideration of regional contexts, the method is transferable to PU regions of other cities in developed nations where demand for land in PU areas is driving LUC from horticulture to housing. The narratives were developed to be consistent with the RCPs and could be applied to other regions. Explanatory variables may be used for other regions: these were selected to ensure coverage of sectors responsible for dominant contributions to anthropogenic emissions. However, regionally specific differences exist that require accommodating, particularly in the life cycle inventory, if the approach were to be used elsewhere. Changing the life cycle inventory (such as dominant crop being displaced by housing; housing types; development patterns; climate zones; and energy mix) is necessary for a study of this type to have regional relevance. Regional relevance is required for effective strategic responses to future uncertainties surrounding climate change.

\subsection{Methodological Approach}

The methodological approach integrated environmental LCA within exploratory scenarios (Figure 1). For each of the four scenarios being analysed, a qualitative narrative describing future characteristics, specifically for housing and food production, was generated. Explanatory variables in support of the narrative were identified. Quantification of explanatory variables permitted incorporation into LCI for each time horizon, 2050 and 2100. GHG impacts were then characterised using LCA software. Each scenario was then compared on relative GHG impact. Potential hotspots within each impact category were identified.

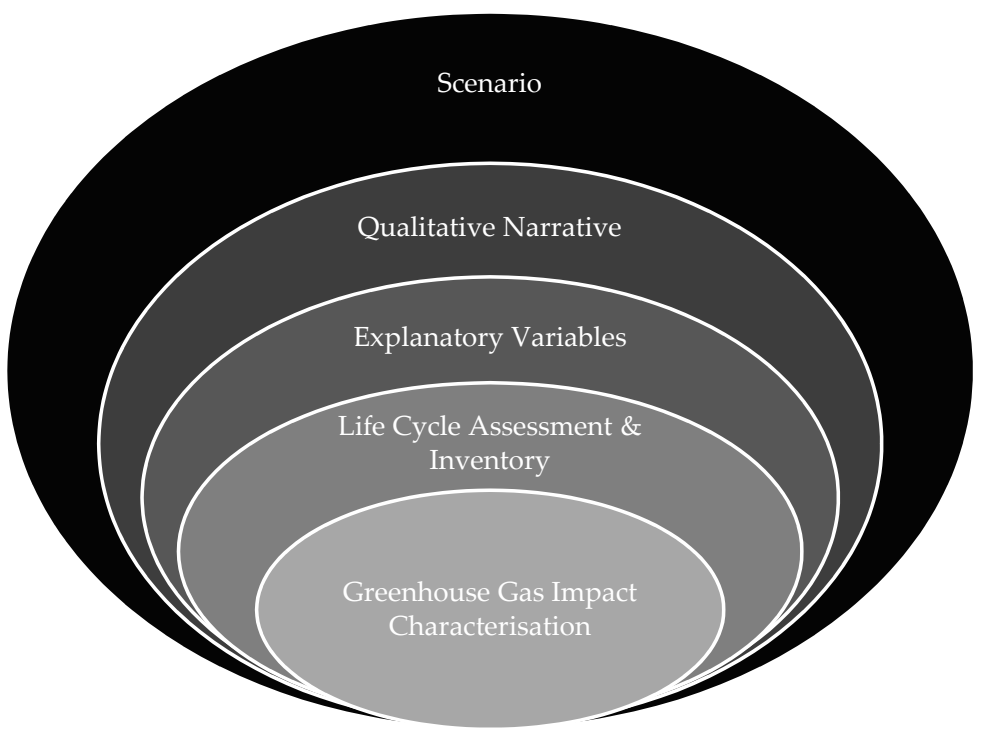

Figure 1. Schematic of research approach.

\subsection{PU Development Narratives}

The fundamental premise behind the narratives was the paradigm, pertinent to a developed and growing city such as Sydney, Australia, that increases in urban population drive additional housing development in both PU and existing suburban locations. The type of housing infrastructure installed 
generates differing amounts of PU LUC and consequential displacement of PU commercial fresh food production.

As a basis for scenario narratives, the four Relative Concentration Pathways (RCPs), as selected by the IPCC for the Fifth Assessment Report [13] were thematically downscaled. The four RCPs cover a range of radiative forcing target levels found in literature for 2100, including RCP2.6 (very low forcing level), RCP4.5 and RCP6 (moderate) and RCP8.5 (high). Each RCP describes how emissions and concentrations change over time, providing data for climate models. Whereas the previous generation of IPCC climate scenarios generated climate projections based on defined socio-economic pathways [16], the RCPs lock in the emissions trajectory rather than the socio-economic circumstances [25]. However, each RCP does include basic underlying assumptions on GDP, policy, population and some socio-economic development [13,20-23]. In order to remain qualitatively consistent with the RCPs, the stated RCP assumptions were adapted in this study through the narrative characteristics to the local PU regional level. Such an approach is feasible as the socio-economic scenarios underlying RCPs are not unique $[13,14]$. Consistency of the scenarios with historical local scale data was assured by using a common baseline from which scenarios then diverged. Ensuring consistency of scenarios between original source and local scale information is suggested as an essential criterion for any downscaling [26].

As the aim of this paper was to explore the combined GHG impacts of both feeding and housing future urban populations in 2050 and 2100, characteristics relevant to urban growth and agricultural change were represented in the narratives. From the housing perspective, central to the analysis was how population change, housing form, transportation mode, technology, temperature trajectory, fuel and energy mix influenced scenarios. Central to the analysis from the agricultural perspective were: the quantity of lettuce displaced by new housing in PU locations; the yield adjusted quantity and land area of lettuce grown at a more remote location; transportation to the Sydney city market; changes in climatic conditions; farm inputs; and total factor productivity changes.

\subsection{Explanatory Variables}

Explanatory variables supporting the narratives (Table 1) and included in this study have been described (Table 2) and quantified (Table 3). Variables selected exhibited a direct relationship to the narrative, such as population trajectory, primary energy mix, technology change and urban form, emissions concentrations and temperature changes. Additionally, explanatory variables were selected to ensure coverage of sectors responsible for dominant contributions to anthropogenic emissions. Recent analysis from the IPCC [31] suggests the following sectors dominate anthropogenic emissions, accounting for approximately 70 percent: electricity and heat production, buildings, transport, agriculture and LUC. Consequently, variables such as primary energy mix, household heating/cooling energy, household and food transportation (mode, technology and fuel mixes), construction, lettuce production, on-farm refrigeration, direct and indirect LUC were included. Furthermore, the explanatory variables were able to explain greater than 80 percent of variation in GHG impact within the current day baseline [15]. 
Table 1. Narratives for the four future urban development scenarios: high emissions; moderately-high emissions; moderately-low emissions; and low emissions.

\begin{tabular}{|c|c|}
\hline $\begin{array}{l}\text { Scenario Name } \\
\text { Characteristic }\end{array}$ & Narrative Description for Characteristic \\
\hline \multicolumn{2}{|c|}{ High Emissions (business as usual) } \\
\hline GHG Emissions & $\begin{array}{l}\text { High emissions, leading to approximately } 1230 \mathrm{ppm} \mathrm{CO}_{2}-\mathrm{e} \text { at } 2100 \text { [27]. Rising emissions are linked to the fossil-intensive energy sector as well as increasing } \\
\text { population and associated food production requirements [13,21]. The high emissions scenario is reflective of a business as usual approach to climate change [21]. }\end{array}$ \\
\hline Population & High growth $[13,21,28,29]$. \\
\hline Energy & $\begin{array}{l}\text { Primary energy consumption rises threefold compared to year } 2000 \text {. Coal and other fossil sources dominate the primary energy mix. Post } 2050 \text {, conventional oil } \\
\text { experiences a dramatic decline. Coal (and gas) sources of petroleum would potentially be required [21]. Introduction of nuclear energy and renewable energies } \\
\text { is characterised by slow adoption. }\end{array}$ \\
\hline Technology & $\begin{array}{l}\text { Technological innovation is slow with limited international technology trading [21,29]. Little adoption of electric vehicles due to low market penetration of } \\
\text { renewable energy sources. }\end{array}$ \\
\hline Economy & Slow income growth and slow convergence of international economic equity drive low efficiency gains and high energy demands [21]. \\
\hline Environmental & Global forest area continues to decrease. Areas of cropland and grassland continue to increase $[13,21]$ \\
\hline Urban growth & $\begin{array}{l}\text { Diffuse suburbanisation and higher land-use change: road infrastructure and automobile dependence permit continued growth in suburban and peri-urban } \\
\text { (PU) areas. Few planning restrictions. }\end{array}$ \\
\hline Agricultural change & $\begin{array}{l}\text { Lower agricultural productivity [28]. Increased food requirements for the growing population are met through transformation of land from other agricultural } \\
\text { land or from native ecosystems. Minimal restrictions on land use change (LUC). }\end{array}$ \\
\hline \multicolumn{2}{|c|}{ Moderately-high emissions } \\
\hline GHG Emissions & Moderate emissions, leading to approximately 728ppm $\mathrm{CO}_{2}$-e at 2100 [27]. \\
\hline Population & Moderate growth $[13,20,28,29]$. \\
\hline Technology & $\begin{array}{l}\text { Technological innovation is diverse, but moderate in adoption pace [23]. Increasing use of CCS at power plants means a greater adoption of hybrid, then fully } \\
\text { electric vehicles compared to the high emissions scenario. }\end{array}$ \\
\hline Economy & Economic development is moderate $[20,29]$. Less global convergence than within the moderately-low emissions narrative. \\
\hline Environment & Areas of cropland continue to increase, but grassland decreases. Forested area experiences a marginal increase $[13,20]$ \\
\hline Urban growth & $\begin{array}{l}\text { Diffuse growth in outer urban areas occurs, but with somewhat more concentration around existing town centres compared to the high scenario. Although road } \\
\text { transportation is still of high influence, a shift to public transport occurs with a slightly higher level of infilling around existing hubs. }\end{array}$ \\
\hline Agriculture & $\begin{array}{l}\text { Historical trends of agricultural productivity decline [22]. A more moderate rate of innovation and technological change occurs compared to the moderately } \\
\text { low emissions narrative, excluding } \mathrm{CO}_{2} \text { fertilisation effects. }\end{array}$ \\
\hline
\end{tabular}


Table 1. Cont

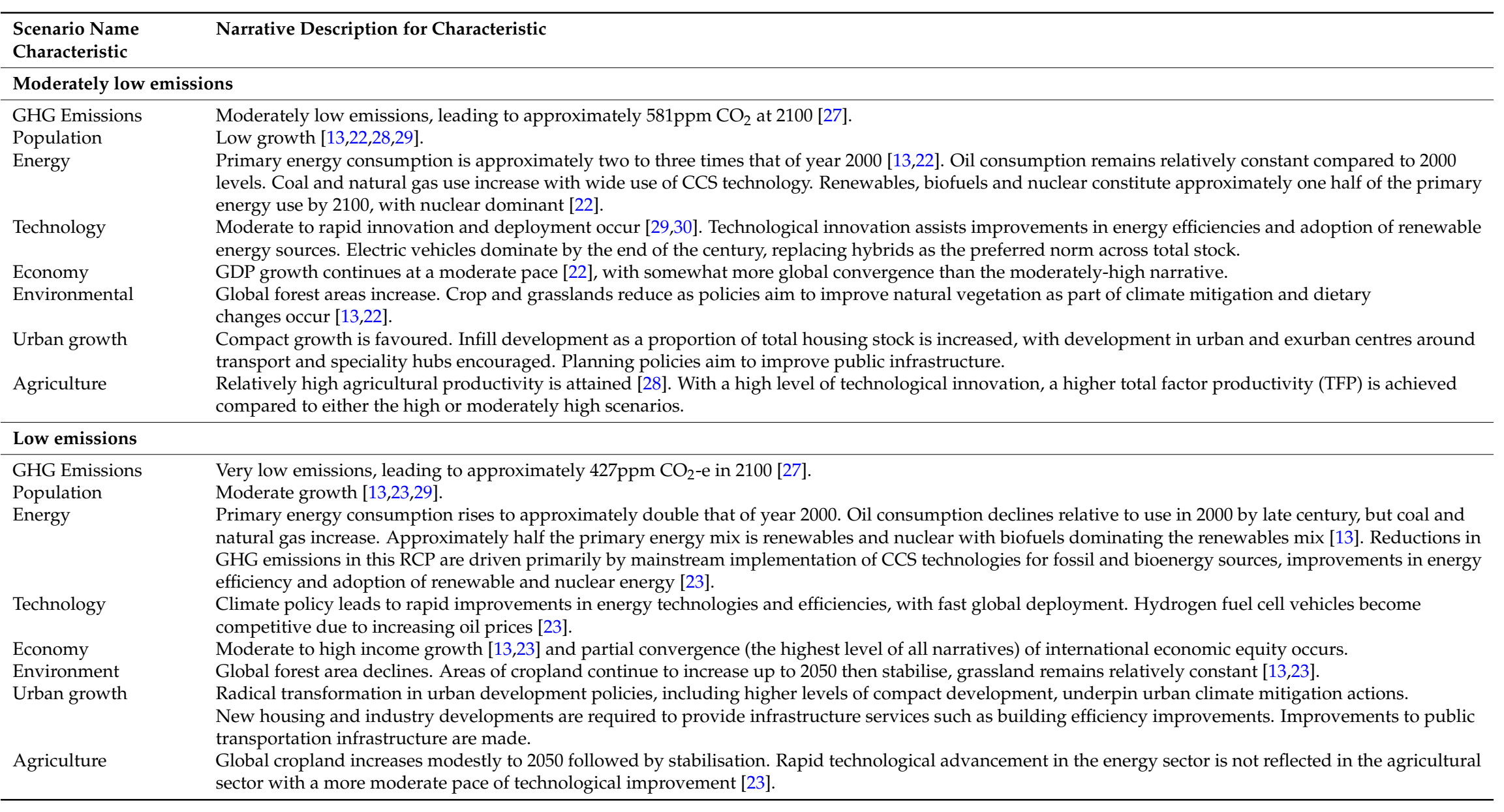


Table 2. Explanatory variables supporting narratives for the four future urban development scenarios.

\section{Explanatory Variable}

Population

Temperature

$\mathrm{CO}_{2}$

Primary energy mix

Housing system

\section{Proportion Infill to}

Greenfield housing

Size of greenfield land parcel

Persons per household

House construction

Direct land-use change

Household operational energy

Household transportation, transportation technology and fuel efficiency

\section{Description}

The population of the Sydney basin followed the high, medium or low population growth trajectories (Series A, B or C respectively) extrapolated to 2100 [32]. Temperature data (mean monthly maximum, Tmax) was produced for each of the scenarios by the CSIRO Climate Projections Outreach Service using a maximum consensus approach for the regions under study. The maximum consensus approach uses the full suite of climate models to project temperature, a maximum consensus approach for the regions under study. The maximum consensus approach uses the full suite of climate models to project temperature,
identifying the climate future supported by the largest number of models, typically resulting in a climate future of intermediate impact, as opposed to a best or worst case situation, for each RCP. Following identification of the maximum consensus climate future for each RCP, climate models were statistically ranked in order to select the most representative models from which temperature was calculated [33]. Temperature increase results were applied to 1986-2005 baseline average monthly mean maximum temperature for each location [34].

$\mathrm{CO}_{2}$-equivalent concentration data per narrative was downloaded from the CMIP5 RCP database, as derived from [27]. $\mathrm{CO}_{2}$ equivalence data aggregated from all anthropogenic forcings were used. Baseline annual global mean $\mathrm{CO}_{2}$-equivalent concentration data was taken from Mauna Loa Observatory [35] Developed from supporting RCP literature [20-23] and IPCC Special Report on Emissions Scenarios OECD 90 data [36]. Where CCS was used, a negative credit for $\mathrm{CO}_{2}$-e emissions was given based on the proportion of electricity generated from fossil sources (coal/gas) and biomass (assumed from ethanol production), subject to CCS at the respective timepoint, assuming 90 percent efficiency of CCS

The proportion of infill to greenfield housing development was based on objectives in the Sydney Metropolitan Plan [37]. Ratio changes from 70:30 infill:greenfield, in favour of infill as narratives tend to lower emissions.

Average land parcel size for a house in a greenfield development reduced to $400 \mathrm{~m}^{2}$ in 2050 and $350 \mathrm{~m}^{2}$ in 2100. Reductions reflect current trends [38] Average household size in a greenfield location (3 persons) and infill location (2 persons) were based on Australian Bureau of Statistics data for representative areas [15]

Amortised over 50 years.

Amortised over 20 years. Direct LUC refers to services installation, soil organic carbon changes due to impervious surface installation (e.g., concrete house slabs) and earth and civil works such as roads [15].

Baseline household operational energy (heating/cooling requirements) for both housing in greenfield and infill locations was determined in [15] using data from the Australian Energy Regulator [39]. A baseline of $7764 \mathrm{kWh}$ and $5307 \mathrm{kWh}$ respectively was used.

Increase in heating/cooling energy use with climate change related temperature rise for a 5 star house was estimated from [40]. A value for autonomous energy efficiency improvement (AEEI) of between 0.25 and 0.75 percent was applied dependent upon the rate of technological change within each narrative. Household transportation data representative of both outer suburban greenfield housing development and inner suburban infill medium storey apartments was adapted from [15] to establish a baseline of transport mode differentiated between private car, public bus and train use. Household transportation was on the basis of person kilometres $(\mathrm{km})$ travelled by car, train or bus. Total household person kms remained static for each housing type at the two time horizons. Allocation of travel kms differed between narratives depending upon modal shift, vehicle and fuel type. Modal shifts from private car use to public

transportation were dependent upon the level and type of urbanisation and technology change occurring. For car travel, person kms were allocated according to the vehicle type defined in Table 3. For vehicles taking liquid fuels, the ratio of liquid fuel was a factor of efficiency gain and fuel types per time point. 
Table 2. Cont

\begin{tabular}{|c|c|}
\hline Explanatory Variable & Description \\
\hline \multicolumn{2}{|l|}{ Food system } \\
\hline Production location & $\begin{array}{l}\text { Displacement of lettuce production from PU Sydney due to urbanisation assumes food is replaced by production from regional locations (e.g., Victoria) in an } \\
\text { inelastic market. Sensitivity of lettuce to monthly mean maximum temperatures above } 28^{\circ} \mathrm{C} \text { may cause further displacement of production to more southerly } \\
\text { climate-capable regions (e.g., Tasmania). }\end{array}$ \\
\hline Lettuce yield change & $\begin{array}{l}\text { Yield change was calculated as a function of } \mathrm{CO}_{2} \text { concentration and temperature rise [41] for each time point, combined with a factor for technological change. } \\
\text { Yield changes were assumed to be an increase in head weight per lettuce, meaning that the number of crop cycles per year was assumed static. Technology } \\
\text { change was captured in a modified TFP measure. TFP in Australian horticulture is approximately } 1 \text { percent. TFP measures implicitly include historical } \\
\text { increases in } \mathrm{CO}_{2} \text {. Decoupling technical change from } \mathrm{CO}_{2} \text { effects suggests a lower rate of change due to production technology than the stated } 1 \text { percent } \\
\text { average would be appropriate [42]. TFP applied in this study ranged between } 0.5 \text { and } 0.8 \text { percent depending on narrative. }\end{array}$ \\
\hline Lettuce transplants & The number of transplants per ha was considered static. Any change in inputs for transplant production was a function of yield change. \\
\hline Plants per hectare & An average planting density of 50,000 plants per ha was assumed. Planting rates per ha remained static over the time period considered. \\
\hline $\mathrm{N}: \mathrm{P}: \mathrm{K}$ fertiliser & Function of yield change. \\
\hline Farm machinery use & Function of yield change. \\
\hline $\begin{array}{l}\text { Farm capital production } \\
\text { (e.g., machinery, } \\
\text { irrigation, sheds) }\end{array}$ & Static, amortised over relevant lifetimes depending upon equipment, for example 15 years tractor, 5 years hoe. \\
\hline Pesticide/herbicide/insecticide & Function of yield change. \\
\hline Water use & Function of yield change. \\
\hline $\begin{array}{l}\text { Electricity on-farm } \\
\text { (e.g., pumps) }\end{array}$ & Function of yield change, using energy mix and AEEI relevant to narrative. \\
\hline $\begin{array}{l}\text { On-farm emissions } \\
\text { (e.g., } \mathrm{N}_{2} \mathrm{O} \text { from fertiliser, } \\
\text { VOC from pesticides) }\end{array}$ & Function of yield change. \\
\hline Crop cycles per annum & Static at 4.5 crop cycles per annum \\
\hline Post-harvest washing & Function of yield change. \\
\hline $\begin{array}{l}\text { Packaging crates - } \\
\text { polypropylene }\end{array}$ & $\begin{array}{l}\text { Assumes all farms use polypropylene crates as opposed to single use cardboard cartons. Prior research has indicated that plastic crates may be preferable } \\
\text { where cardboard products are not recycled at end-of-life [43]. No change to quantity of crates required at } 12 \text { head per crate. }\end{array}$ \\
\hline Coolroom & $\begin{array}{l}\text { No change to capital infrastructure inventory. Refrigeration energy is accounted for as a change in electricity mix and AEEI. Refrigeration power demand was } \\
\text { measured in [44] as a function of outdoor temperature, finding an increase of approximately } 1.7 \text { percent per degree celcius. Increase in energy due to rising } \\
\text { temperatures was tested for the Sydney PU farm, finding only a minor impact on GHG emissions (less than } 0.25 \text { percent). Consequently, accounting for } \\
\text { changes in coolroom energy as a function of change in Tmax was not performed for the scenarios. }\end{array}$ \\
\hline Transportation to market & $\begin{array}{l}\text { No modal shift from road to other forms of transport was modelled for the food supply chain. Distance to the central Sydney fruit and vegetable market was } \\
\text { based on road distance by truck and, where necessary, sea freight between Tasmania and mainland Australia. }\end{array}$ \\
\hline Indirect land-use change & Indirect LUC because of further upstream crop displacements was evaluated under sensitivity testing, using the model of [45]. \\
\hline
\end{tabular}


Table 3. Quantification of explanatory variables.

\begin{tabular}{|c|c|c|c|c|c|c|c|c|}
\hline \multirow{3}{*}{ Variable } & \multicolumn{8}{|c|}{ Scenario } \\
\hline & \multicolumn{2}{|c|}{ High Emissions } & \multicolumn{2}{|c|}{ Moderately-High Emissions } & \multicolumn{2}{|c|}{ Moderately-Low Emissions } & \multicolumn{2}{|c|}{ Low Emissions } \\
\hline & 2050 & 2100 & 2050 & 2100 & 2050 & 2100 & 2050 & 2100 \\
\hline Population, million (currently 4.7 ) & 7.9 & 13.2 & 7.7 & 11.2 & 7.4 & 9.1 & 7.7 & 11.2 \\
\hline Housing ratio, infill (IF) :greenfield (GF) & $70: 30$ & $70: 30$ & $80: 20$ & $85: 15$ & $85: 15$ & 95:5 & $85: 15$ & 95:5 \\
\hline \multirow{3}{*}{$\begin{array}{l}\text { Primary energy mix, } \\
\text { coal:gas:nuclear:biomass:renewable }\end{array}$} & 65:20:0: & 55:15:5: & 45:35:5: & 30:40:8: & 45:22:10: & 30:20:20: & 25:45:10: & 15:35:15: \\
\hline & 5: 10 & 7: 18 & 5: 10 & 7: 15 & 13:10 & 15:15 & 10:10 & \\
\hline & $\operatorname{CCS} 5 \%$ & CCS $30 \%$ & CCS $10 \%$ & CCS $70 \%$ & CCS $15 \%$ & CCS $80 \%$ & CCS $67 \%$ & CCS $90 \%$ \\
\hline \multicolumn{9}{|l|}{ Transportation } \\
\hline Household modal shift & $83: 12: 5 \mathrm{GF}$ & $80: 15: 5$ GF & 77:218:5 GF & 70:25:5 GF & 70:25:5 GF & 60:35:5 GF & $65: 30: 5 \mathrm{GF}$ & $50: 45: 5 \mathrm{GF}$ \\
\hline car:train:bus & 73:15:12 IF & 70:18:12 IF & 64:21:15 IF & 53:30:17 IF & $55: 28: 17 \mathrm{IF}$ & 40:40:20 IF & 45:35:20 IF & 20:60:20 IF \\
\hline Fossil fuel efficiency gain across stock, $\%$ & 20 & 30 & 25 & 40 & 35 & 50 & 45 & 60 \\
\hline & BF 5 & BF 7 & BF 5 & BF 12 & BF 10 & BF 15 & BF 15 & BF 30 \\
\hline Alternative liquid fuels for car transport, $\%$ & NG 15 & NG 15 & NG 15 & NG 20 & NG 20 & NG 30 & NG 40 & NG 20 \\
\hline$\left(\right.$ for ICE ${ }^{1} \mathrm{~s}$ and hybrids) ${ }^{2}$ & $\begin{array}{l}\text { CTL/GIL } \\
50\end{array}$ & $\begin{array}{l}\text { CIL/GIL } \\
75\end{array}$ & GTL 50 & GTL 60 & & & CTL 10 & CTL 30 \\
\hline & HE 60 & HE 85 & HE 60 & HE 65 & HE 60 & HE 15 & HE 40 & HE 10 \\
\hline Vehicle type, ICE replaced with ${ }^{3}, \%$ & E 2 & E 10 & E 10 & E 30 & E 20 & E 80 & E 40 & E 50 \\
\hline & $\mathrm{H}_{2} \mathrm{FCV} 0$ & $\mathrm{H}_{2} \mathrm{FCV} 0$ & $\mathrm{H}_{2} \mathrm{FCV} 0$ & $\mathrm{H}_{2} \mathrm{FCV} 0$ & $\mathrm{H}_{2}$ FCV 0 & $\mathrm{H}_{2} \mathrm{FCV} 0$ & $\mathrm{H}_{2}$ FCV 10 & $\mathrm{H}_{2}$ FCV 40 \\
\hline \multicolumn{9}{|l|}{ Household operational energy and electricity use } \\
\hline Autonomous energy efficiency improvement (AEEI) & 0.25 & 0.25 & 0.40 & 0.40 & 0.60 & 0.60 & 0.75 & 0.75 \\
\hline \multicolumn{9}{|l|}{ Food system } \\
\hline $\mathrm{CO}_{2}$-e concentration, ppm & 628 & 1230 & 505 & 728 & 526 & 581 & 455 & 427 \\
\hline Modified total factor productivity (TFP), \% pa & 0.5 & 0.5 & 0.6 & 0.6 & 0.7 & 0.7 & 0.8 & 0.8 \\
\hline Average annual temperature, Tmax, changes, ${ }^{\circ} \mathrm{C}$ & 1.8 & 3.7 & 1.3 & 2.5 & 1.4 & 2.0 & 1.0 & 0.9 \\
\hline
\end{tabular}

Note: ${ }^{1}$ ICE—Internal combustion engines; ${ }^{2} \mathrm{BF} —$ biofuel; NG—natural gas; CTL—coal to liquid diesel; GTL—gas to liquid diesel; ${ }^{3} \mathrm{HE}-$ hybrid electric vehicle using fossil ICE and

battery; E-electric; FCV—hydrogen fuel cell vehicle. 


\subsection{Life Cycle Assessment and Inventory}

LCI describing a housing system and a horticultural system (Figure 2), to be adapted as a baseline for this study, was established in [15]. Two forms of housing were modelled: outer suburban development in greenfield areas; and infill 4 to 6 storey apartment housing on existing vacant urban land. Lettuce production was modelled as outdoor field production. Commonalities between field farms were identified to establish the lettuce field production baseline for the purposes of this study.

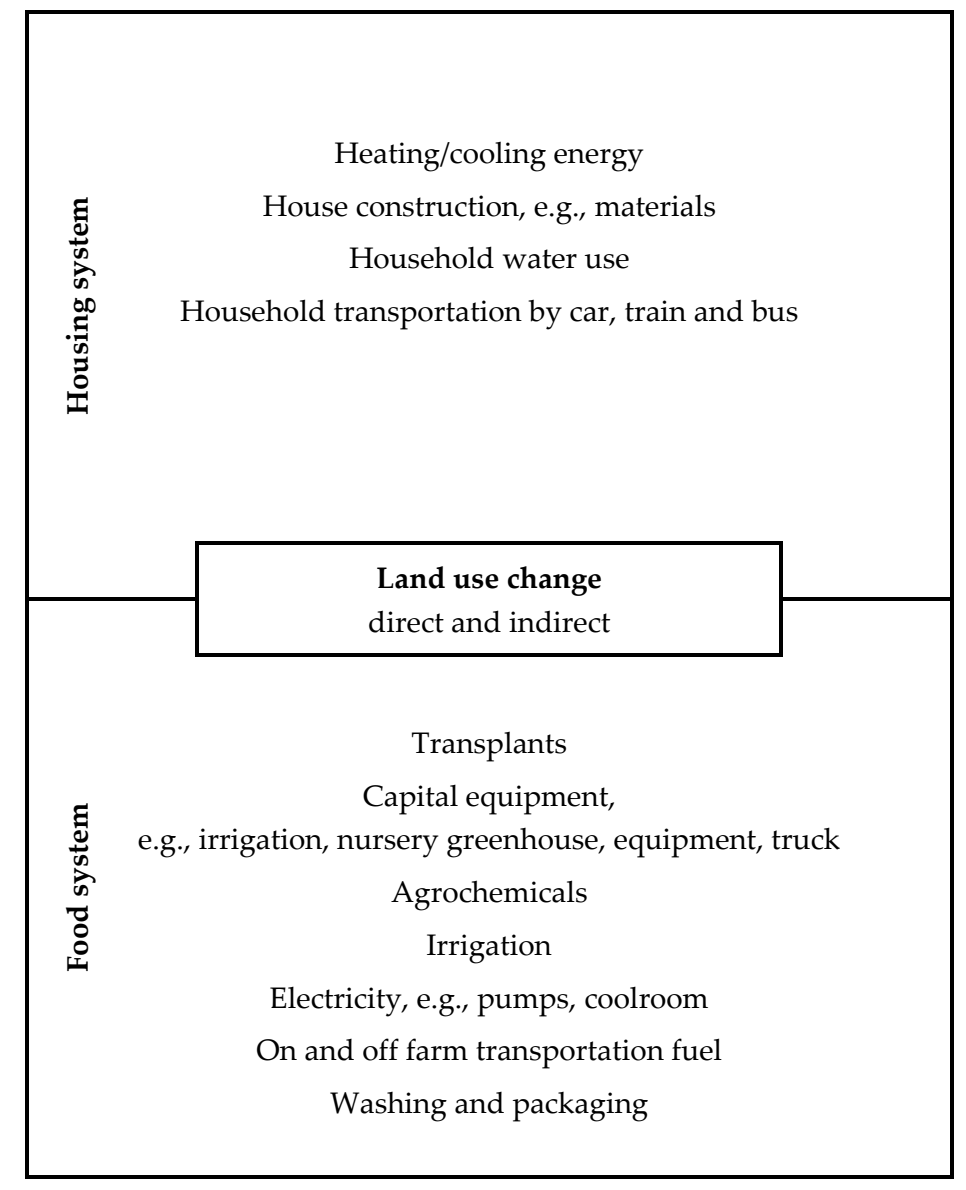

Figure 2. Life cycle inventory (LCI) for the housing and food systems contained within scenarios.

Housing LCI included inputs of household water use, passenger kilometres by car, train or bus, electricity use, construction materials (such as cement, concrete, ceramics, doors, copper, glass, wood, paint, plasterboard, plastics, steel and insulation). Lettuce LCI inputs addressed: transplants over growth phase until planting (including fertilisers, water, sand, peat moss, plastic trays, steel and polyethylene for the transplant houses); on farm use of N, P, K fertiliser, water, farm bikes, tractors, agricultural machinery (e.g., hoes), metal and polyethylene for irrigation, pesticides, and electricity; post-harvest processing such as washing, crates, refrigeration infrastructure and electricity; and transport to market by road (Figure 2) [15]. To maintain regional relevance, primary data for the temporal baseline were informed by farmers and urban developers.

Furthermore, direct (dLUC) and indirect land-use change (iLUC) were included. Earlier work has shown that dLUC aspects when transitioning land use to housing, including changes to soil organic carbon (SOC) when impervious surfaces (roads, concrete) are installed, services infrastructure (telecommunications, sewer and water) and civil and bulk earthworks, to be of potential significance for GHG emissions. For the same reason, iLUC occurring as a result of the dLUC, including upstream anthropogenic land-use change due to further crop displacements, was included [19]. This iLUC 
occurs to compensate for lost crop production from the PU area. The iLUC component is therefore based on arable land displacement. It is worthwhile to note that if a reduction in infill densification were to occur, more greenfield housing could be required, inducing further PU LUC and subsequently increasing the iLUC contribution. Detailed analysis to assess densification changes to infill housing to determine associated land expansion and emissions impacts would be a subject of future work.

LCI for the housing and food systems were modified as influenced by the explanatory variables. As an example, the 2050 electricity mix for the high emissions scenario comprised 65, 20, 5 and 10 percent electricity from coal, gas, biomass and renewables, per proportions listed in Table 3 . Furthermore, a cut-off criteria of 1 percent of total GHG impact was used to determine which inventory required modification at each future time horizon. For example, due to the relatively high contribution of upstream electricity in potable water production, the electricity mix within water production inventory was corrected to that of the appropriate time horizon. Similarly, concrete and steel used in construction were modified for the energy mix pertinent at the time.

Data handling at each time horizon included a determination of new hectares of greenfield housing required as a function of growth in population, housing type proportion, persons per household and greenfield land parcel size. The theoretical yield of lettuce that could have otherwise been grown on this area was established, adjusting for climatic variables of temperature and $\mathrm{CO}_{2}$ changes pertinent at the time horizon. This theoretical yield required replacement from a more remote location, in this case approximately $900 \mathrm{~km}$ south in Victoria, Australia. Victoria was the modelled remote location for three reasons: current competition with PU production; transportation distances similar to those found for imported fresh produce in other regions of the world (for example Mediterranean produce being sent to other parts of Europe); and rising temperatures that are likely to increase lettuce production in cooler southerly latitudes.

In this paper, the value of LCA is in quantifying relative environmental performance between scenarios (that have the same system boundary), not necessarily in establishing absolute GHG emission values. Establishing relative trends between scenarios, provides valuable guidance on ramifications of interventions that differ between scenarios and dominant hotspots. Using regionally specific primary data (such as that obtained through farmers and developers) serves to improve data accuracy. However the inherent nature of LCA requires use of secondary data in the background. For example, the farmer provides quantity and type of fertiliser used, but the emissions associated with the production of fertiliser were obtained from a database, in this case the widely used EcoInvent database [46]. Using LCA for comparative assessment is therefore preferred. Some inconsistency in the temporal aspect of baseline data necessarily occurs due to the multiple data streams and sources used for LCI. For example, population data were projected from 2014, the transportation survey used to indicate household travel by mode was conducted in 2010-2011, household operational energy was provided from 2015, Tmax change projections involve a 1986-2005 baseline and baseline annual $\mathrm{CO}_{2}$ emissions from 2014 were used. The impact is not expected to alter trends observed as each of the four scenarios were developed from the same baseline and have the same system boundary.

\subsection{Environmental Impact Characterisation}

SimaPro 8.0.5.13 software using the Ecoinvent 3 unit process database [46] was used for characterisation of GHG impact. The primary functional unit was the amount of PU land transformed under each scenario. Results were reported firstly by total area of PU land transformed under each scenario and secondly, normalised by population change for the relevant time horizon and city region. Total GHG emissions ( $\mathrm{kg} \mathrm{CO}_{2}$-e) per time horizon and scenario were calculated using the ReCiPe hierarchical method [47]. For iLUC calculations, the iLUC model (version 4.0) described in [45] was used. In the absence of international consensus for modelling iLUC, this model was selected for reasons of compatibility with SimaPro LCI and its empirical basis, where both intensification and expansion effects are included: iLUC impacts in the arable land market include both intensification of existing arable land and transformation from forest. 


\subsection{Sensitivity}

Scenarios implicitly evaluate sensitivity to those variables identified in Table 3. Sensitivity to two further variables was assessed: further food displacement effects due to impact of Tmax on lettuce growing thresholds; and sensitivity to years of impact for iLUC. No other food system variables were tested for sensitivity due to the low overall impact of the food system.

\subsubsection{Tmax}

Lettuce has a critical temperature threshold of $28^{\circ} \mathrm{C}$ (mean monthly maximum) above which growth may be compromised (Lovatt et al., Wheeler et al., Wurr et al. in [48]). Sensitivity of growing location to Tmax changes was considered at the 2100 time horizon.

\subsubsection{Indirect Land-Use Change}

Further potential upstream agricultural land-use modifications were considered through the variable of iLUC. Such upstream land-use changes, such as deforestation, may occur in order to compensate for lost crop production.

Sensitivity was not assessed for the moderately-low or moderately-high scenarios. The moderately-low and moderately-high scenarios experience increases in forested areas (Table 1), hence it was assumed that iLUC effects were transient with no overall deforestation.

However, for the low and high emissions scenarios, deforestation continues for some period of time: in the low emissions scenario, to 2050; while in the high emissions scenario there is no cessation of deforestation. The implication for the high and low emissions scenarios, given the permanence of urbanisation combined with increasing populations requiring feeding, is that the years of impact of iLUC increase beyond the default of 1 year. In order to bound a potentially infinite number of iLUC years of impact, sensitivity to several time periods was evaluated, including up to 50 years of iLUC impact.

\section{Results}

GHG emissions results for each scenario are reported by area of PU land consumed to house the change in population (Figure 3). GHG emissions, per area of PU land consumed and normalised per the population change of Greater Sydney at the respective time horizon, are provided in Figure 4. Presenting results on a per capita basis for the population change at the respective time horizon provides a comparison of anthropogenic emissions caused by each additional person who comes to reside in Greater Sydney. The corresponding amount of PU land absorbed by housing and the quantity of associated fresh food displacement is detailed in Table 4.

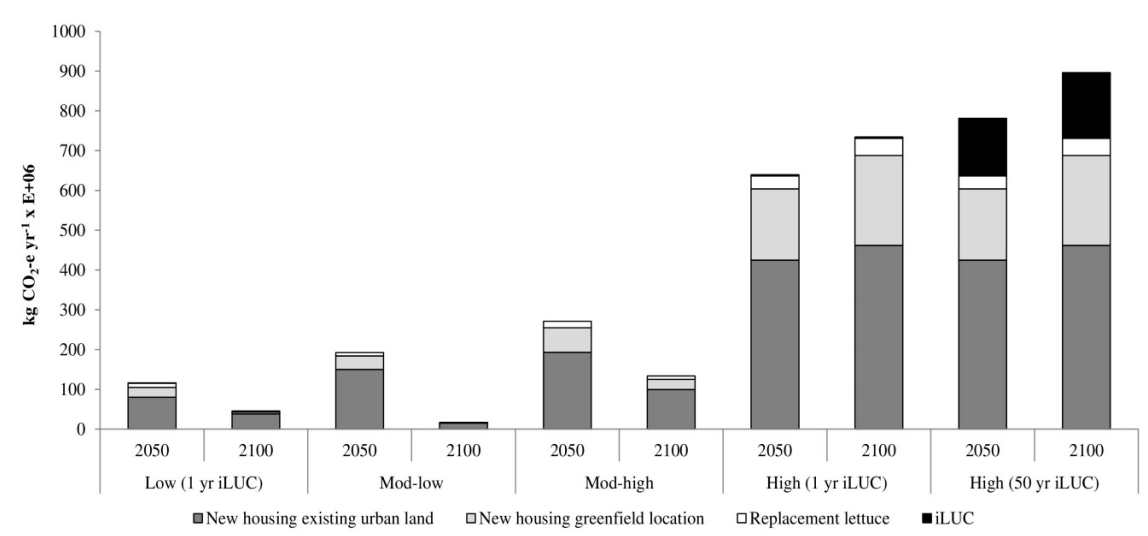

Figure 3. GHG emissions impact ( $\mathrm{kg} \mathrm{CO}_{2}$-e) per area of peri-urban (PU) land transformed for housing under the four future scenarios at time horizons 2050 and 2100. Contributions are displayed from the components: new housing in existing urban location; new housing in greenfield location; replacement lettuce; and iLUC. 


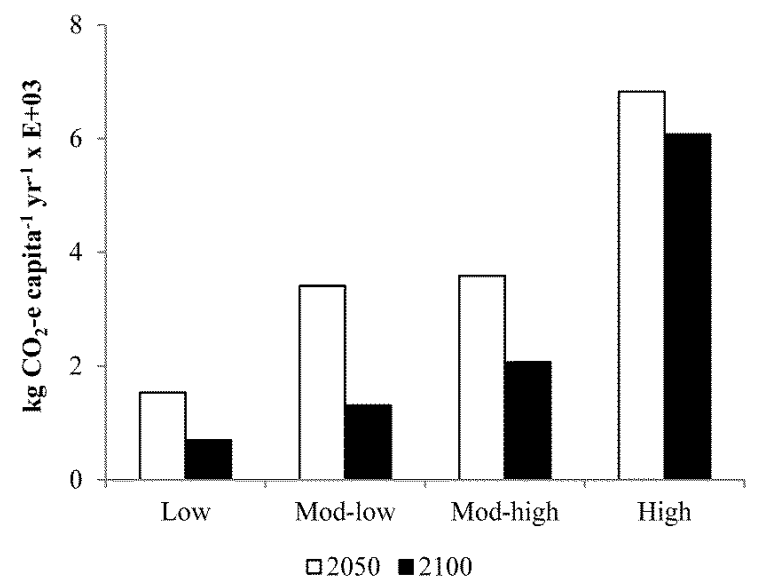

Figure 4. GHG emissions ( $\mathrm{kg} \mathrm{CO}_{2}$-e yr-1) per area of PU land transformed normalised for population change, under the four future scenarios at time horizons 2050 and 2100.

Table 4. PU land consumption by new housing in greenfield areas and associated food displacement under the four future scenarios.

\begin{tabular}{ccccc}
\hline & \multicolumn{2}{c}{$\mathbf{2 0 5 0}$} & \multicolumn{2}{c}{2100} \\
\hline Scenario & $\begin{array}{c}\text { New Housing } \\
\text { (ha) }\end{array}$ & $\begin{array}{c}\text { Quantity Lettuce Displaced } \\
(\mathbf{t})\end{array}$ & $\begin{array}{c}\text { New Housing } \\
\text { (ha) }\end{array}$ & $\begin{array}{c}\text { Quantity Lettuce Displaced } \\
\text { (t) }\end{array}$ \\
\hline Low & 224 & 4661 & 56.3 & 1924 \\
Moderately-low & 167 & 3579 & 11.3 & 408 \\
Moderately-high & 298 & 6341 & 169 & 6545 \\
High & 551 & 12,431 & 626 & 30,690 \\
\hline
\end{tabular}

The importance of selecting a functional unit appropriate for the study purpose becomes apparent when results are compared expressed per $\mathrm{kg}$ of displaced lettuce (Figure 5). LCA results for horticultural products are often presented on a per $\mathrm{kg}$ basis. Viewing the results per $\mathrm{kg}$ of displaced lettuce as in Figure 5, at first glance, presents a favourable result for the higher emissions scenarios. This occurs due to a higher amount of PU LUC causing a higher quantity of lettuce displacement. However, the quantity of lettuce requiring replacement to maintain market supply at equitable food volumes is significantly higher in these higher emissions scenarios. The purpose of including results per $\mathrm{kg}$ of lettuce here is to illustrate the importance of designing LCA studies for purpose, keeping the bigger picture in mind. Reporting per total area of LUC as in Figures 3 and 4 provides a more correct and comprehensive perspective on environmental impacts due to PU LUC.

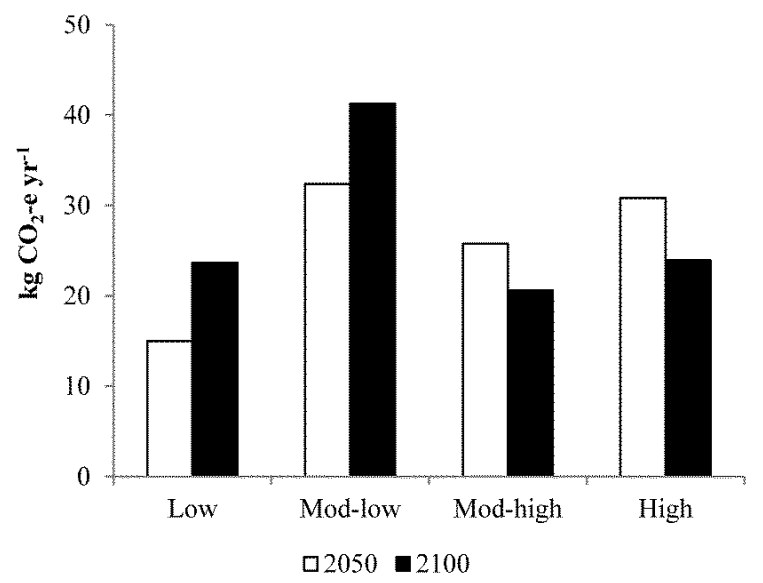

Figure 5. GHG emissions ( $\mathrm{kg} \mathrm{CO}_{2}$-e yr-1) per $\mathrm{kg}$ of displaced lettuce under the four future scenarios at time horizons 2050 and 2100. 


\subsection{GHG Emissions}

The housing system contributed 90 to 95 percent of GHG emissions across all 2050 scenarios, primarily due to household operational energy use followed by transportation impacts. Replacing displaced food from a more remote location to the Sydney market contributed 5 to 10 percent of total scenario GHG emissions. The dLUC aspects of the PU LUC (services infrastructure, SOC changes due to covering previously open land with impervious surfaces and civil and bulk earthworks) incurred approximately 2 to 4.5 percent of total GHG impact.

The dominant hotspot for GHG emissions across all scenarios and time horizons was the use of coal and natural gas in electricity mixes, principally for household operation. At the 2050 time horizon, the assumptions surrounding higher use of CCS (two-thirds market penetration) combined with a primary energy mix of one-third renewables and nuclear in the low emissions scenario produced electricity impacts at 46 percent of total scenario GHG emissions. In contrast, electricity represented 64 to 73 percent of total GHG emissions in the moderately-low, moderately-high and high emissions scenarios.

Household transportation was a second GHG emissions hotspot. In 2050, household car travel represented between 8 and 22 percent of GHG emissions, being for the moderately-low and high emissions scenarios respectively. The low emissions scenario has a greater gain in fossil fuel efficiency, higher biofuel use, a lower use of internal combustion engines and a larger modal shift from car to public transport than the moderately-low scenario. However, the contribution of household car travel to overall GHG impact (14 percent) is larger compared with the moderately-low scenario, driven by the larger population change requiring housing and the consequent larger change in PU land use from food production to housing. Train and bus transportation consistently return less than 4 percent of GHG impact across scenarios.

The cement component used in construction of apartments in the housing system is a third hotspot for GHG emissions in the low and moderately low scenarios. For example, at the 2100 time horizon, emissions from cement production incur 21 and 17 percent of total emissions respectively. Producing cement requires large quantities of energy and produces large amounts of $\mathrm{CO}_{2}$ emissions, partly due to the energy required and also due to the calcination process of converting limestone (calcium carbonate) into calcium oxide and $\mathrm{CO}_{2}$. In this study, no CCS was applied to the $\mathrm{CO}_{2}$ generated in the limestone conversion. It would be a reasonable expectation that the two lower emissions scenarios would experience fewer impacts from the $\mathrm{CO}_{2}$ aspect of cement production if $\mathrm{CCS}$ were included for cement production.

Surprisingly, the moderately-low emissions scenario exhibited the lowest GHG emissions impact as a function of PU land transformed at year 2100. A lower emissions impact is explained by this scenario possessing the lowest population growth: the moderately-low scenario is the only low population growth scenario. Lower population growth has driven less demand for new housing in greenfield areas, thereby causing less PU LUC. However, when normalised for population per capita emissions follow the expected trend. Per capita emissions are higher than the low scenario, despite the moderately-low scenario sharing the same ratio of housing type. Higher per capita emissions result from less market penetration of carbon capture and storage technology and a reduced modal shift to electric and hydrogen fuel cell vehicles for household transportation.

At the 2100 time horizon, changes in the primary energy mix favouring CCS, nuclear and renewables, combined with improved energy efficiencies, reduced the contribution of electricity to scenario GHG emissions. Electricity impacts declined to 21, 49 and 59 percent respectively for the low, moderately-low and moderately-high scenarios. Reduced electricity impacts occurred despite increases in household operational energy used for space cooling coinciding with rising temperatures. For example, in the moderately-high scenario a $2.5^{\circ} \mathrm{C}$ average annual Tmax rise approximately doubled household operational energy compared with that of the baseline. However, with an electricity mix including one-third nuclear, biomass and renewables and 70 percent market penetration of CCS, the electricity contribution to GHG impact declined from 70 percent at the 2050 time horizon to 59 percent 
in 2100. In the low emissions scenario, electricity use for household operation experienced a net decline by 2100 due to assumed energy efficiency improvements outweighing the corresponding increase in cooling energy required for an average annual Tmax rise of $0.9^{\circ} \mathrm{C}$. In contrast, for the high 'business as usual' scenario, electricity contribution to GHG impact increased from 55 percent in 2050 to 79 percent in 2100. This increasing result was due to the additional household operational energy required for an average Tmax rise of $3.7^{\circ} \mathrm{C}$, after accounting for an AEEI rate of 0.25 percent, combined with low market penetration of CCS and a primary energy mix dominated by fossil sources.

\subsection{Sensitivity Testing}

\subsubsection{Tmax Effects}

Scenarios were not sensitive to Tmax effects on lettuce seasonality. Tmax effects could potentially reduce the growing season in regional Victoria, under the high emissions scenario in 2100, by approximately two months. However, analysis determined that this 'worst case' scenario was not sensitive to bringing lettuce from Tasmania for a two month period to complement regional production.

\subsubsection{Indirect LUC}

GHG emissions were sensitive to assumptions pertaining to iLUC. At the 2050 time horizon, the default one year of iLUC contributed a low 1 percent or less to overall scenario GHG impact. However, 10 years of iLUC impact increased total GHG emissions to approximately 9 percent for the low emissions scenario and 4 percent for the high emissions scenario. Further years of impact were evaluated for the high emissions scenario, as no cessation of deforestation occurs. At the 2100 time horizon, twenty years of iLUC impact increased GHG emissions by 9 percent, while 50 years of impact resulted in a 23 percent increase in total GHG emissions. The changes in percent contributions to total scenario emissions are illustrated in Figure 6.

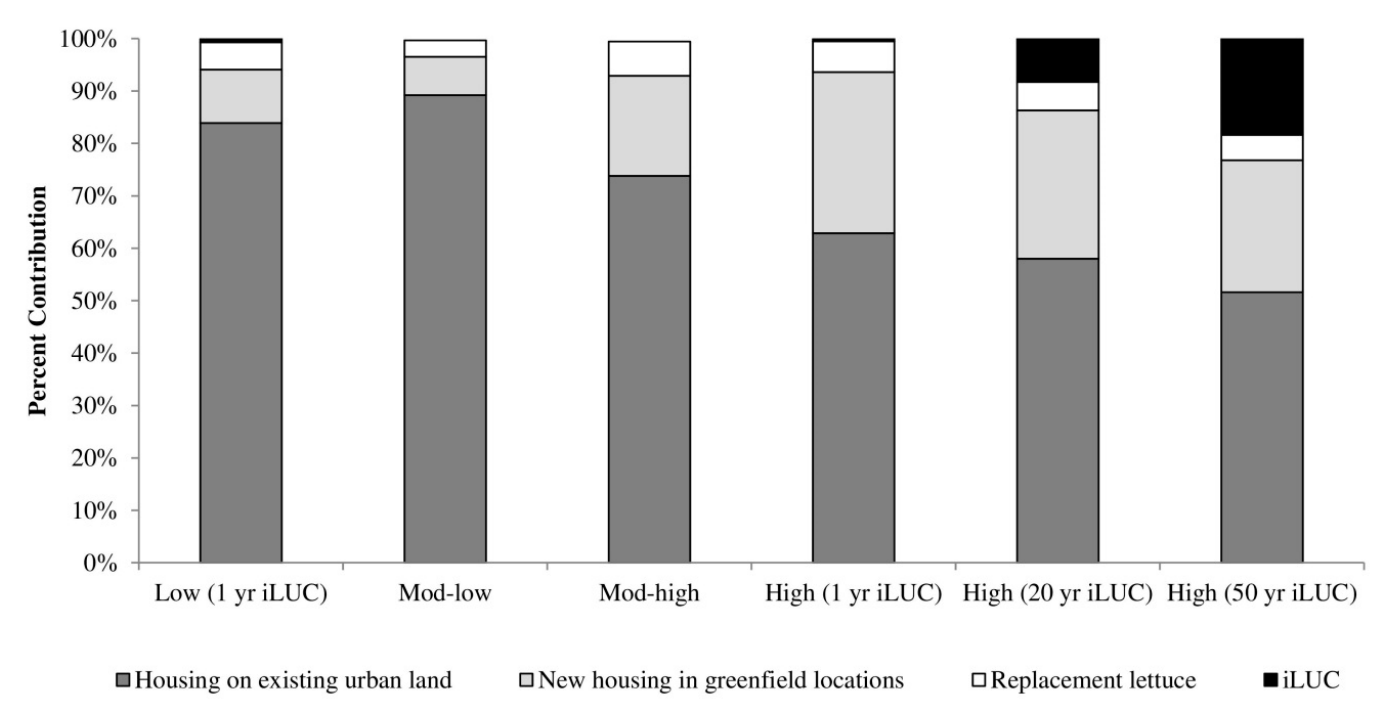

Figure 6. Percent contribution of infill housing on existing urban land; new housing in greenfield locations; replacement of PU lettuce; and indirect land use change to GHG emissions per area of PU land transformed for the four future scenarios at time horizon 2100.

\section{Discussion}

Recent per capita emissions in Australia approximate $16.5 \mathrm{t} \mathrm{CO}_{2}$-e per annum, the 12th highest globally [49]. The GHG emissions per capita of new residents at the 2050 and 2100 time horizons (Figure 4), due to the PU LUC induced to feed and house the growing urban population, represented between 4 and 43 percent increases to this average per capita level. A more comprehensive examination 
of GHG changes across other sectors would be required to assess how such increases compromise efforts to meet Australian reduction targets. What has been shown, however, is that the increase in GHG emissions due to the urbanisation of PU land appears significant enough to warrant further attention.

The difference in GHG emissions between the high and low emissions scenarios was approximately $0.7 \mathrm{Mt} \mathrm{CO}_{2}$-e per year at the 2100 time horizon. If such differences were incurred throughout other Australian capital cities, this result could potentially be an order of magnitude larger. To put this into context, Australia's road transport emissions in 2012 were $77 \mathrm{Mt} \mathrm{CO}_{2}$-e and domestic aviation $7 \mathrm{Mt} \mathrm{CO}_{2}$-e. Domestic aviation, domestic shipping and rail together account for less than $1 \mathrm{Mt}$ $\mathrm{CO}_{2}$-e of abatement in 2020 and $3 \mathrm{Mt} \mathrm{CO}_{2}$-e of abatement in 2030, mainly due to fuel switching in domestic aviation [50].

Pursuing a national low emissions approach to housing development, with robust, proactive climate policies, as opposed to a business as usual approach, may provide a potentially valuable mitigation opportunity. Minimising greenfield development in favour of infill housing in existing urban locations with retention of PU horticultural land additionally minimises unknown upstream iLUC effects, the impact of which could be large. Furthermore, future constraints around water and arable land availability in more remote locations may further confound the ability to replace displaced PU horticultural production, the examination of which would need to be the subject of future research.

National Australian reduction targets required $126 \mathrm{Mt} \mathrm{CO}$-e of absolute abatement for the year 2019-2020 in order to achieve a 5 percent reduction on 2000 levels [51]. Recently established 2030 targets, requiring 26 to 28 percent reductions on 2005 emissions, require 19 to 22 percent reductions on 2000 levels. However, relative to 2000, 2012 GHG emissions in Australia rose by approximately $14 \mathrm{MtCO}_{2}$-e to $600 \mathrm{MtCO}_{2}$-e, or 2.5 percent. Emissions are predicted to increase a further $85 \mathrm{MtCO}_{2}$-e in 2020, or 17 percent higher than 2000 levels [50]. Given the overall aim of reducing absolute $\mathrm{CO}_{2}$ emissions, maintaining a business as usual approach to PU LUC and urban development, as in the high emissions scenario, potentially compromises these targets. The lock-in GHG risk associated with installing permanent housing infrastructure in PU locations would require additional decarbonisation in other sectors to offset growth in emissions due to continued PU LUC.

Furthermore, the locked-in nature of greenfield housing in outer suburban regions compromises future capacity to capitalise on technology changes in the food production sector. By consuming land for housing, less land remains to allow for future installation of alternative technology food production systems, such as high technology greenhousing. The capability of these high technology food systems to increase output at lower GHG impact and improve resilience of urban communities is, to date, understated.

Improving knowledge of the type of interventions that may affect the greatest emissions reductions in order to feed and house urban populations is important for policy makers. The low and moderately-high scenarios have identical population trajectories, meaning that differences between these scenarios serve to illustrate how assumptions surrounding energy mix, housing form and transportation may change GHG emissions. For example, at the 2050 time horizon, electricity contributed 46 percent of GHG impact in the low, versus 70 percent in the moderately-high scenario. Influencing this difference was the estimated market penetration of 67 percent CCS in the low and 10 percent in the moderately-high emissions scenario. However, CCS technology currently remains in the development stages, with unproven commercial viability at large scale. Exacerbating viability issues in the current Australian context is uncertain investment support for clean energy. How carbon reductions will be achieved without significant market penetration of CCS and a renewables friendly economy is not clear. A further difference driving lower emissions was the increased proportion of infill housing in the low scenario. Yet actual implementation of higher density dwellings around existing urban centres is fraught with challenge. Startling differences between public opinion and government policy exist, with residents preferring a significantly lower level of higher density housing combined with low acceptance levels for increasing density in one's own suburb [52]. Implementing interventions 
such as CCS with higher density housing may require a paradigmatic shift. A shift that incorporates cross-sectoral energy saving measures into urban planning at the regional scale [53].

Electricity was the foremost driver of emissions. For the low, moderately-low and moderately-high emissions scenarios, the contribution of electricity, and overall GHG impact, declined from 2050 to 2100. Critically, this decline was not observed in the high emissions scenario. In contrast, in this business as usual approach, GHG emissions increased in 2100, with electricity due to household operation increasing by a considerable 47 percent. This large increase serves to highlight the importance of assumptions not only around the use of CCS, but as importantly, the impact of climate change on household operational requirements in mixed climate zones. In a mixed climate zone such as Sydney, the increased need for cooling energy, particularly in greenfield style development, should drive the need for further backcasting studies with spatial relevance. Backcasting studies may assist investigation into housing standards and geographic constraints relevant to mitigation under particular climatic outcomes.

Indirect LUC effects are not considered in national estimates of projected land use and LUC, which has potential ramifications for transparency. In 2012, emissions from the land use, LUC and forestry (LULUCF) sector in Australia accounted for $21 \mathrm{Mt} \mathrm{CO}_{2}-\mathrm{e}, 4$ per cent of Australia's total emissions [50]. This study finds that contribution from 50 years of iLUC impact in the high scenario, considering that no cessation of deforestation occurs, approximates $0.15 \mathrm{Mt} \mathrm{CO}_{2}$-e per annum, or 0.7 percent of Australian 2012 LULUCF emissions. If similar business as usual urban consumption patterns are found across the nation, the iLUC affect would be proportionally larger and not insignificant. Even when only the default one year of iLUC impact is considered, differences in total GHG emissions between the low and high scenarios approximate 3 percent of Australian LULUCF emissions. If such figures were to be considered at a national scale, the emissions impact of PU LUC due to urban consumption is compelling. However, PU LUC is not typically considered in LULUCF accounting as it is not classed as afforestation, reforestation, or deforestation. Other ramifications of iLUC effects on public policy could include impacts on estimates of urban ecological footprints. Urban ecological footprints are designed to estimate the amount of natural capital extracted to support an urban area and are frequently used as a policy communication tool [54]. Not considering iLUC impacts associated with displacement of horticultural production from PU areas would result in the biophysical inputs appropriated by urban residents being underestimated. Further transparency of LUC accounting for estimation and mitigation reasons should consider PU LUC due to urban development.

Interestingly, it is the intensification aspect of iLUC, as opposed to the land expansion component, that is responsible for increased influence as the more years of iLUC impact are chosen. Similarly, modelling performed for RCP8.5 in [21] determined that one quarter of the rise in GHG emissions was due to intensification of agricultural production and associated increase in fertiliser use and $\mathrm{N}_{2} \mathrm{O}$ emissions (while the remaining three quarters was from the energy sector).

\section{Limitations}

Storylines exclude abrupt perturbations of climate such as droughts or floods. No argument is made as to the realism of these scenarios. The politics and nature of economic reform that may be required to address future demands on government finances and government capacity to respond were not considered. Policy interventions that would support a scenario may not exist: policy examination is out of scope. Evidence exists to suggest that technology may not be adapted at the rapidity required, with labour productivity growth dominating per capita incomes, as opposed to multifactor productivity [55]. Urban heat island effects were not considered. Similarly, neither were any increased urban cooling effects due to urban afforestation.

\subsection{Lettuce}

The scenarios assume PU land displaced was all food producing land, modelled as lettuce. Obviously other agricultural systems occur on displaced land, the consideration of which would 
require an expansion in the number of assessments. Changes in temperature, precipitation and $\mathrm{CO}_{2}$ levels may alter both the crop cycle duration and the seasonality of the crop. Interactions of other climate variables (such as ozone), changes in crop water requirements, crop maturation, spoilage, pest and disease issues and market elasticity were not considered. Furthermore, water scarcity was not examined. How water availability and withdrawals will change in each geographical location would require detailed hydrological modelling. Ready availability of inputs, such as fertilisers, was not challenged. Potential underestimation for Tmax at the 2100 time point may occur as available temperature data was averaged for the period 2080-2100, reflective of 2090. High technology production forms that may supplement displaced vegetable production were not included. For the Australian context, with very little adaptation of high technology growing systems, the way in which alternative growing technologies might be adopted remained ill-defined and hence not included in quantitative modelling. How different levels of adoption would influence results would be a valuable comparison in future research.

\subsection{Transport}

The same gains in fuel efficiency were applied to cars, trucks and buses, which may overestimate gains for trucks used during lettuce delivery and for bus transportation. Electricity from renewable sources was the power source for electric cars and buses. Buses and trucks with internal combustion engines were assumed to use either diesel or biofuel. Cars with internal combustion engines additionally used petrol and natural gas in the fuel mix. Buses included only internal combustion and electric vehicles. Keeping household kilometres static under future scenarios is a simplistic assumption, as total household kilometres may change with future urban development. However the degree to which this may occur in the future is unknown and a simple approach was justified.

\subsection{Energy}

CCS infrastructure was not included as no relevant LCI was located at the time of this study. Renewable energy was split 50:50 into wind and solar. Adjustment to household operational energy with temperature rise was based on average monthly Tmax changes, as opposed to mean monthly temperature changes, which may generate slight but not significant differences in the overall scenario trends. Future household operational energy applied to a 5 star house. The star rating of houses in Australia refers to the level of thermal energy performance of a building within a climate zone, ranging from a low of zero to outstanding thermal performance at a rating of 10 stars. Currently, average star rating of existing housing stock is approximately 2 stars (Energy research for the building code of Australia in [40]). A 5 star house has been identified as being optimal from a thermal efficiency gain vs cost benefit [56]. New detached houses are typically built to a 6 star rating, with apartments 3.5 stars, meaning that over time, housing stock average will increase relative to current stock and without the influence of climate change. Assuming a 5 star rating would overestimate current stock averages but as more stock is built the average would be expected to approach higher ratings given a static climate.

\section{Conclusions}

This study evaluated GHG emission trends under four future urban development scenarios, at 2050 and 2100 time horizons. The exploratory scenarios were designed as tools to engage with uncertainty surrounding possible future GHG emission impacts associated with peri-urbanisation. Results show that differences in approaches to housing future urban populations have significance for mitigation. Embracing fresh food production is a necessary component when evaluating resilience of urban areas and associated environmental impacts of PU development. However, strategic focus on urban form, primary energy mix and carbon capture and storage technologies would be appropriate to ensure larger mitigation opportunities are realised for urban development in PU regions. To capitalise on mitigation opportunities, current politico-legal structures and associated cross-functional linkages 
require deeper analysis and change. Further development of these scenarios would require feedback from policy makers.

Acknowledgments: We would like to thank John Clarke from CSIRO Marine and Atmospheric Research for temperature projections. PhD scholarship funding and open access funding was provided by Western Sydney University, Australia and the Commonwealth Scientific and Industrial Research Organisation (CSIRO), Australia.

Author Contributions: A. Rothwell, B. Ridoutt and W. Bellotti conceived the approach; A. Rothwell performed the research, analysed the data and wrote the paper; B. Ridoutt and W. Bellotti provided essential critical feedback during paper development.

Conflicts of Interest: The authors declare no conflict of interest. The founding sponsors had no role in the design of the study; in the collection, analyses, or interpretation of data; in the writing of the manuscript, and in the decision to publish the results.

\section{Abbreviations}

The following abbreviations are used in this manuscript:

$\begin{array}{ll}\text { AEEI } & \text { Autonomous energy efficiency improvement } \\ \text { BF } & \text { Biofuel } \\ \text { CCS } & \text { Carbon capture and storage } \\ \text { CMIP5 } & \text { Coupled Model Intercomparison Project Phase 5 } \\ \text { CO}_{2} & \text { Carbon dioxide } \\ \text { CTL } & \text { Coal to liquid } \\ \text { dLUC } & \text { Direct land use change } \\ \text { E } & \text { Electric } \\ \text { FCV } & \text { Fuel cell vehicle } \\ \text { GF } & \text { Greenfield } \\ \text { GHG } & \text { greenhouse gas } \\ \text { GTL } & \text { Gas to liquid } \\ \text { H2 } & \text { Hydrogen } \\ \text { HE } & \text { Hybrid electric } \\ \text { ICE } & \text { Internal combustion engine } \\ \text { IF } & \text { Infill } \\ \text { iLUC } & \text { Indirect land use change } \\ \text { IPCC } & \text { Intergovernmental Panel on Climate Change } \\ \text { LCA } & \text { Life cycle assessment } \\ \text { LCI } & \text { Life cycle inventory } \\ \text { LUC } & \text { Land use change } \\ \text { LULUCF } & \text { Land use, land use change and forestry } \\ \text { MDPI } & \text { Multidisciplinary Digital Publishing Institute } \\ \text { N } 2 \mathrm{O} & \text { Dinitrogen monoxide } \\ \text { NG } & \text { Natural gas } \\ \text { PU } & \text { Peri-urban } \\ \text { RCP } & \text { Relative Concentration Pathway } \\ \text { SOC } & \text { Soil organic carbon } \\ \text { TFP } & \text { Total Factor Productivity } \\ \text { USA } & \text { United States of America }\end{array}$

\section{References}

1. Seto, K.; Dhakal, S.; Bigio, A.; Blanco, H.; Delgado, G.; Dewar, D.; Huang, L.; Inaba, A.; Kansal, A.; Lwasa, S.; et al. Human settlements, infrastructure, and spatial planning. In Climate Change 2014: Mitigation of Climate Change. Contribution of Working Group III to the Fifth Assessment Report of the Intergovernmental Panel on Climate Change; Edenhofer, O., Pichs-Madruga, R., Sokona, Y., Farahani, E., Kadner, S., Seyboth, K., Adler, A., Baum, I., Brunner, S., Eickemeier, P., et al., Eds.; Cambridge University Press: Cambridge, UK, 2014; pp. 923-1000.

2. United Nations Human Settlements Programme. Cities and Climate Change: Global Report on Human Settlements 2011; Earthscan Ltd.: London, UK, 2011.

3. Barredo, J.I.; Gómez, M. Towards a set of IPCC SRES urban land use scenarios: Modelling urban land use in the Madrid region. In Modelling Environmental Dynamics; Paegelow, M., Olmedo, M., Eds.; Springer: Berlin/Heidelberg, Germany, 2008; pp. 363-385. 
4. Bierwagen, B.G.; Theobald, D.M.; Pyke, C.R.; Choate, A.; Groth, P.; Thomas, J.V.; Morefield, P. National housing and impervious surface scenarios for integrated climate impact assessments. Proc. Natl. Acad. Sci. USA 2010, 107, 20887-20892. [CrossRef] [PubMed]

5. Reginster, I.; Rounsevell, M. Scenarios of future urban land use in Europe. Environ. Plan. B 2006, 33, 619-636. [CrossRef]

6. Solecki, W.D.; Oliveri, C. Downscaling climate change scenarios in an urban land use change model. J. Environ. Manag. 2004, 72, 105-115. [CrossRef] [PubMed]

7. Viguié, V.; Hallegatte, S.; Rozenberg, J. Downscaling long term socio-economic scenarios at city scale: A case study on Paris. Technol. Forecast. Soc. 2014, 87, 305-324. [CrossRef]

8. Wheeler, S.M.; Tomuta, M.; Haden, V.R.; Jackson, L.E. The impacts of alternative patterns of urbanization on greenhouse gas emissions in an agricultural county. J. Urban. 2013, 6, 213-235. [CrossRef]

9. Haight, D.; Ten Eyck, L.; Arjomand, S. Cultivate New York: An Agenda to Protect Farmland for Growing Food and the Economy; American Farmland Trust: New York, NY, USA, 2016. Available online: https:/ /www.farmland.org/ publications (accessed on 19 November 2016).

10. Australian Bureau of Statistics. 7503.0 - Value of Agricultural Commodities Produced, Australia, 2012-13, 'Table 2: Value of Agricultural Commodities Produced, State and NRM Region-New South Wales-2012-13', data cube: Excel spreadsheet, cat. no. 75030DO002_201213; Australian Bureau of Statistics (ABS): Canberra, ACT, Australia, 2014.

11. Thompson, E.; Harper, A.M.; Kraus, S. Think Globally-Eat Locally: San Francisco Foodshed Assessment; American Farmland Trust: Washington, DC, USA, 2008.

12. Shaffer, S.; Thompson, E. A New Comparison of Greenhouse Gas Emissions from California Agricultural and Urban Land Uses; American Farmland Trust: Davis, CA, USA, 2015.

13. Van Vuuren, D.; Edmonds, J.; Kainuma, M.; Riahi, K.; Thomson, A.; Hibbard, K.; Hurtt, G.; Kram, T.; Krey, V.; Lamarque, J.-F.; et al. The representative concentration pathways: An overview. Clim. Chang. 2011, 109, 5-31. [CrossRef]

14. IPCC Data Distribution Centre. Scenario Process for AR5 Representative Concentration Pathways (RCPs). Available online: http://sedac.ciesin.columbia.edu/ddc/ar5_scenario_process/RCPs.html (accessed on 4 June 2016).

15. Rothwell, A.; Ridoutt, B.; Page, G.; Bellotti, W. Feeding and housing the urban population: Environmental impacts at the peri-urban interface under different land-use scenarios. Land Use Policy 2015, 48, 377-388. [CrossRef]

16. Nakicenovic, N.; Alcamo, J.; Davis, G.; de Vries, B.; Fenhann, J.; Gaffin, S.; Gregory, K.; Grübler, A.; Jung, T.; Kram, T.; et al. Special Report on Emissions Scenarios: A Special Report of Working Group III of the Intergovernmental Panel on Climate Change; Cambridge University Press: Cambridge, UK, 2000.

17. Head, B.W. Evidence, uncertainty, and wicked problems in climate change decision making in Australia. Environ. Plan. C 2014, 32, 663-679. [CrossRef]

18. Wright, G.; Cairns, G. Scenario Thinking: Practical Approaches to the Future; Palgrave Macmillan: Basingstoke, UK, 2011.

19. Rothwell, A.; Ridoutt, B.; Page, G.; Bellotti, W. Direct and indirect land-use change as prospective climate change indicators for peri-urban development transitions. J. Environ. Plan. Manag. 2015, 59, 643-665. [CrossRef]

20. Masui, T.; Matsumoto, K.; Hijioka, Y.; Kinoshita, T.; Nozawa, T.; Ishiwatari, S.; Kato, E.; Shukla, P.R.; Yamagata, Y.; Kainuma, M. An emission pathway for stabilization at $6 \mathrm{Wm}^{-2}$ radiative forcing. Clim. Chang. 2011, 109, 59-76. [CrossRef]

21. Riahi, K.; Rao, S.; Krey, V.; Cho, C.; Chirkov, V.; Fischer, G.; Kindermann, G.; Nakicenovic, N.; Rafaj, P. RCP 8.5-A scenario of comparatively high greenhouse gas emissions. Clim. Chang. 2011, 109, 33-57. [CrossRef]

22. Thomson, A.; Calvin, K.; Smith, S.; Kyle, G.P.; Volke, A.; Patel, P.; Delgado-Arias, S.; Bond-Lamberty, B.; Wise, M.; Clarke, L.; et al. RCP4.5: A pathway for stabilization of radiative forcing by 2100. Clim. Chang. 2011, 109, 77-94. [CrossRef]

23. Van Vuuren, D.; Stehfest, E.; den Elzen, M.J.; Kram, T.; van Vliet, J.; Deetman, S.; Isaac, M.; Klein Goldewijk, K.; Hof, A.; Mendoza Beltran, A.; et al. RCP2.6: Exploring the possibility to keep global mean temperature increase below $2{ }^{\circ} \mathrm{C}$. Clim. Chang. 2011, 109, 95-116. [CrossRef]

24. Malcolm, P.; Fahd, R. Ground Truthing of Sydney Vegetable Industry in 2008; Department of Primary Industries: Orange, NSW, Australia, 2009. 
25. Department of Environment. Representative Concentration Pathways (RCPS); Department of Environment: Canberra, ACT, Australia, 2013.

26. Van Vuuren, D.P.; Smith, S.J.; Riahi, K. Downscaling socioeconomic and emissions scenarios for global environmental change research: A review. Wiley Interdiscip. Rev. Clim. Chang. 2010, 1, 393-404. [CrossRef]

27. Meinshausen, M.; Smith, S.J.; Calvin, K.; Daniel, J.S.; Kainuma, M.L.T.; Lamarque, J.F.; Matsumoto, K.; Montzka, S.A.; Raper, S.C.B.; Riahi, K.; et al. The RCP greenhouse gas concentrations and their extensions from 1765 to 2300. Clim. Chang. 2011, 109, 213-241. [CrossRef]

28. Schweizer, V.; O'Neill, B. Systematic construction of global socioeconomic pathways using internally consistent element combinations. Clim. Chang. 2014, 122, 431-445. [CrossRef]

29. van Vuuren, D.; Carter, T. Climate and socio-economic scenarios for climate change research and assessment: Reconciling the new with the old. Clim. Chang. 2014, 122, 415-429. [CrossRef]

30. O'Neill, B.; Kriegler, E.; Riahi, K.; Ebi, K.; Hallegatte, S.; Carter, T.; Mathur, R.; van Vuuren, D. A new scenario framework for climate change research: The concept of shared socioeconomic pathways. Clim. Chang. 2014, 122, 387-400. [CrossRef]

31. IPCC. Summary for Policymakers. In Climate Change 2014: Mitigation of Climate Change. Contribution of Working Group III to the Fifth Assessment Report of the Intergovernmental Panel on Climate Change; Edenhofer, O., Pichs-Madruga, R., Sokona, Y., Farahani, E., Kadner, S., Seyboth, K., Adler, A., Baum, I., Brunner, S., Eickemeier, P., et al., Eds.; Cambridge University Press: Cambridge, UK, 2014.

32. Australian Bureau of Statistics. 3222.0 - Population Projections, Australia, 2012 (Base) to 2101. Projection Results-States and Territories. Table 3 Projected Population, Components of Change and Summary Statistics, Greater Sydney. Released 26 November 2013; Australian Bureau of Statistics: Canberra, ACT, Australia, 2013.

33. Clarke, J.; Whetton, P.; Hennessy, K. Providing application-specific climate projections datasets: CSIRO's Climate Futures Framework. In Proceedings of 19th International Congress on Modelling and Simulation, Perth, WA, Australia, 12-16 December 2011. Available online: http:/ /mssanz.org.au/modsim2011 (accessed on 4 June 2016).

34. Bureau of Meteorology. Climate Data Online; Bureau of Meteorology: Melbourne, VIC, Australia, 2014. Available online: http://www.bom.gov.au/climate/data/ (accessed on 15 December 2014).

35. Dlugokencky, E.; Tans, P. ESRL Global Monitoring Division-Global Greenhouse Gas Reference Network. Trends in Atmospheric Carbon Dioxide, Global - Globally Averaged Marine Surface Annual Mean Data; National Oceanic and Atmospheric Administration (NOAA)/Earth System Research Laboratory (ESRL): Boulder, CO, USA, 2014. Available online: www.esrl.noaa.gov/gmd/ccgg/trends/ (accessed on 4 June 2016).

36. Nakicenovic, N.; Alcamo, J.; Davis, G.; de Vries, B.; Fenhann, J.; Gaffin, S.; Gregory, K.; Grübler, A.; Jung, T.; Kram, T.; et al. Appendix VII: Data tables in excel-format. In Special Report on Emissions Scenarios: A Special Report of Working Group III of the Intergovernmental Panel on Climate Change; Cambridge University Press: Cambridge, UK, 2000.

37. Department of Planning. Metropolitan Plan for Sydney 2036; NSW Department of Planning: Sydney, NSW, Australia, 2010.

38. Urban Development Institute of Australia. The 2015 UDIA State of the Land Report; Urban Development Institute of Australia (UDIA): Canberra, ACT, Australia, 2015.

39. Australian Energy Regulator. Energy Made Easy: Understand and Compare Your Electricity Usage. Available online: https:/ / www.energymadeeasy.gov.au/benchmark (accessed on 15 December 2014).

40. Wang, X.; Chen, D.; Ren, Z. Assessment of climate change impact on residential building heating and cooling energy requirement in Australia. Build. Environ. 2010, 45, 1663-1682. [CrossRef]

41. Lobell, D.B.; Gourdji, S.M. The influence of climate change on global crop productivity. Plant Physiol. 2012, 160, 1686-1697. [CrossRef] [PubMed]

42. Attavanich, W.; McCarl, B.A. The Effect of Climate Change, $\mathrm{CO}_{2}$ Fertilization, and Crop Production Technology on Crop Yields and Its Economic Implications on Market Outcomes and Welfare Distribution. In Proceedings of the 2011 Annual Meeting, Agricultural and Applied Economics Association, Pittsburgh, PA, USA, 24-26 July 2011; No. 103324.

43. Rothwell, A.; Ridoutt, B.; Page, G.; Bellotti, W. Environmental performance of local food: Trade-offs and food security implications for a developed city. J. Clean. Prod. 2016, 114, 420-430. [CrossRef] 
44. Sarhadian, R. Small Grocery Store Integrated Energy Efficiency Improvements; Refrigeration and Thermal Test Centre Project PY 2002, RTTC Project R02ET01, ET Project ET02.05 Final Report; Refrigeration and Thermal Test Center: Irwindale, CA, USA, 2004.

45. Schmidt, J.; Weidema, B.; Brandão, M. A framework for modelling indirect land use changes in life cycle assessment. J. Clean. Prod. 2015, 99, 230-238. [CrossRef]

46. PRé Consultants, Putting the Metrics behind Sustainability. Available online: http://www.pre-sustainability. com/simapro (accessed on 4 June 2016).

47. Goedkoop, M.; Heijings, R.; Huibregts, M.; De Schryver, A.; Struijs, J.; Van Zelm, R. ReCiPe 2008: A Life Cycle Impact Assessment Method Which Comprises Harmonised Category Indicators at the Midpoint and the Endpoint Level; Report 1: Characterisation, 1st ed.; RIVM, CML, PRé Consultants and Radboud Universiteit Nijmegen: Bilthoven, The Netherlands, 2009. Available online: http:/ / www.lcia-recipe.net (accessed on 4 June 2016).

48. Deuter, P.; White, N.; Putland, D. Critical Temperature Thresholds Case Study: Lettuce; 2012. Available online: http:/ / www.managingclimate.gov.au/publications/lettuce-critical-temperature-thresholds-nowavailable-for-download/ (accessed on 25 June 2012).

49. World Bank Group. Data: $\mathrm{CO}_{2}$ Emissions (Metric Tons per Capita); The World Bank Group, sourced from Carbon Dioxide Information Analysis Center, Environmental Sciences Division, Oak Ridge National Laboratory: Oak Ridge, TN, USA, 2015.

50. Treasury and DICCSRTE. Chapter 3 Australian Projections. In Climate Change Mitigation Scenarios; The Treasury and the Department of Industry, Innovation, Climate Change, Science, Research and Tertiary Education (DIICCSRTE): Canberra, ACT, Australia, 2013; pp. 37-87.

51. Department of the Environment. Australia's Abatement Task Fact Sheet; Department of the Environment: Canberra, ACT, Australia, 2015. Available online: http://www.environment.gov.au/climate-change/ emissions-projections (accessed on 4 June 2016).

52. Ruming, K. Urban consolidation: Strategic planning and community opposition in Sydney, Australia: Unpacking policy knowledge and public perceptions. Land Use Policy 2014, 39, 254-265. [CrossRef]

53. Zanon, B.; Verones, S. Climate change, urban energy and planning practices: Italian experiences of innovation in land management tools. Land Use Policy 2013, 32, 343-355. [CrossRef]

54. Kissinger, M.; Sussman, C.; Moore, J.; Rees, W.E. Accounting for the Ecological Footprint of Materials in Consumer Goods at the Urban Scale. Sustainability 2013, 5, 1960-1973. [CrossRef]

55. Keating, M.; Smith, C. Critical Issues Facing Australia to 2025: Summary of a Scenario Development Forum; Academy of the Social Sciences in Australia: Canberra, ACT, Australia, 2011.

56. Centre for International Economics. Energy-Efficiency: Building Code Star-Ratings. What's Optimal, What's Not; Centre for International Economics: Canberra, ACT, Australia, 2010.

(C) 2016 by the authors; licensee MDPI, Basel, Switzerland. This article is an open access article distributed under the terms and conditions of the Creative Commons Attribution (CC-BY) license (http:/ / creativecommons.org/licenses/by/4.0/). 